\title{
Mitochondrial DNA evidences reflect an incipient population structure in Atlantic goliath grouper (Epinephelus itajara, Epinephelidae) in Brazil
}

\author{
Júnio S. Damasceno ${ }^{1,2}$, Raquel Siccha-Ramirez ${ }^{3,4}$, Millke J.A. Morales ${ }^{3}$, Claudio Oliveira ${ }^{3}$, \\ Rodrigo A. Torres ${ }^{5}$, Edvaldo N. Costa ${ }^{6}$, Gláucia C. Silva-Oliveira ${ }^{7}$, Marcelo Vallinoto ${ }^{7,8}$, \\ Leonardo F. Machado ${ }^{9}$, Vander C. Tosta ${ }^{9}$, Ana Paula C. Farro ${ }^{9}$, Maurício Hostim-Silva ${ }^{9}$ \\ ${ }^{1}$ Programa de Pós-graduação em Oceanografia Ambiental, Departamento de Oceanografia e Ecologia, Base Oceanográfica, \\ UFES - Universidade Federal do Espírito Santo, Rodovia ES 10 km 16, 565, Coqueiral CEP: 29199-970, Aracruz, ES, \\ Brazil. E-mail: jdamascenobh@gmail.com \\ ${ }^{2}$ Laboratório de Genética da Conservação, Programa de Pós-graduação em Zoologia de Vertebrados, PUCMINAS - \\ Pontifícia Universidade Católica de Minas Gerais, Av. Dom José Gaspar 500, Coração Eucarístico, CEP: 30535-901, Belo \\ Horizonte, MG, Brazil. \\ ${ }^{3}$ Laboratório de Biologia e Genética de Peixes, Departamento de Morfologia, Instituto de Biociências de Botucatu, UNESP \\ - Universidade Estadual Paulista, Distrito de Rubião Junior, s/n CEP: 18618-000, Botucatu, SP, Brazil. \\ ${ }^{4}$ Laboratorio Costero de Tumbes, Instituto del Mar del Perú - IMARPE, Calle José Olaya S/N, C.P. Nueva Esperanza, \\ Zorritos, Tumbes, Perú. \\ ${ }^{5}$ Laboratório de Genômica Evolutiva e Ambiental, Departamento de Zoologia, Universidade Federal de Pernambuco, Av. \\ Prof. Nelson Chaves s/n, CEP: 50670-420, Recife, PE, Brazil. \\ ${ }^{6}$ Centro de Pesquisa e Conservação da Biodiversidade do Nordeste, CEPENE/ICMBio, R. Samuel Hardman s/n, Cidade \\ Universitária, CEP: 55587-000, Tamandaré, PE, Brazil. \\ ${ }^{7}$ Laboratório de Evolução, Instituto de Estudos Costeiros, Campus Universitário de Bragança, UFPA - Universidade \\ Federal do Pará, Alameda Leandro Ribeiro, s/n, Bairro Aldeia, CEP: 68600-000, Bragança, PA, Brazil. \\ ${ }^{8}$ InBIO/CIBIO - Centro de Investigação em Biodiversidade e Recursos Genéticos, Campus Agrário de Vairão, \\ Universidade do Porto, R. Padre Armando Quintas, No 7, 4485-661, Vairão, Portugal. \\ ${ }_{9}^{9}$ Departamento de Ciências Agrárias e Biológicas, UFES - Universidade Federal do Espírito Santo, Rodovia BR 101 Norte, \\ Km 60, Litorâneo CEP: 29932-540, São Mateus, ES, Brazil.
}

\begin{abstract}
Summary: The Atlantic goliath grouper is a critically endangered species that inhabits estuarine and reef environments and is threatened primarily by fishing activities and habitat destruction. Despite the urgent need for protection, its genetic conservation status remains unknown. The aim of the present study was to evaluate the gene flow among the populations of the species along the coast of Brazil based on the control region of the mitochondrial DNA. The results indicate low haplotype diversity $(0.40-0.86)$ and very low nucleotide diversity $(0.1-0.5 \%)$. They also show that the genetic diversity of the species varies considerably along the coast and that this finding may be especially important for the identification of priority areas for its conservation. The population analyses indicate a low but significant degree of genetic structuring $\left(\Phi_{\mathrm{ST}}=0.111\right)$, probably due to the occurrence of rare haplotypes at some locations, although the genetic differentiation between sites was not correlated with geographic distance $(\mathrm{r}=0.0501 ; \mathrm{p}=0.7719)$, and the shared haplotypes indicate that gene flow occurs among all locations along the Brazilian coast. The results of the pairwise $\mathrm{F}_{\mathrm{ST}}$ indicate a high degree of genetic differentiation between locations. The incipient population structuring detected in the present study is not related systematically to the geological or physical features of the Brazilian coast. The complex interaction of fluctuations in sea level, marine currents, and the reproductive characteristics of the species hampers the identification of the specific role of each of these processes in the gene flow dynamics of the population units of the Atlantic goliath grouper. The low overall levels of genetic diversity, the pairwise $\mathrm{F}_{\mathrm{ST}}$ values and the significant population structuring among groups $\left(\Phi_{\mathrm{CT}}\right)$ identified in the present study all reinforce the critically endangered status of the species and are inconsistent with the presence of a single, panmictic population of groupers on the Brazilian coast. The results of this study suggest that, though it may be incipient, the observed genetic structuring must be taken into account in order to prevent potential problems, such as outbreeding depression, in the management of wild stocks.
\end{abstract}

Keywords: critically endangered species; gene flow; genetic diversity; marine fish; western Atlantic Ocean.

Evidencias en el ADN mitocondrial reflejan una incipiente estructuración poblacional en el mero guasa del Atlántico (Epinephelus itajara, Epinephelidae) en Brasil

Resumen: El mero guasa del Atlántico está críticamente en peligro, habita en ambientes estuarinos y arrecifes, los cuáles están amenazados principalmente por las actividades de pesca y la destrucción de su hábitat. A pesar de la necesidad urgente de protección, su estado de conservación genética aún es desconocido. El objetivo del presente estudio fue evaluar el flujo génico entre las poblaciones de esta especie a lo largo de la costa de Brasil analizando la variabilidad genética de la región control del ADN mitocondrial. Los resultados indican baja diversidad haplotípica (0.40-0.86), y una muy baja diversidad 


\begin{abstract}
nucleotídica (0.1-0.5\%). Además se observa que la diversidad genética de la especie varía considerablemente a lo largo de la costa y este resultado puede ser especialmente relevante para la identificación de áreas prioritarias de conservación. Los análisis poblacionales indican un bajo, pero significativo grado de estructuración genética $\left(\Phi_{\mathrm{ST}}=0.111\right)$, lo cual es probablemente debido a la ocurrencia de haplótipos raros en algunas localidades, aunque la diferenciación genética entre sitios no está correlacionada con la distancia geográfica $(\mathrm{r}=0.0501$; $\mathrm{p}=0.7719)$, y los haplotipos compartidos indican que el flujo génico ocurre entre todas las localidades a lo largo de la costa brasileña. Los resultados de la distancia dos a dos indican un $\mathrm{F}_{\mathrm{ST}}$ de alto grado de diferenciación genética entre las localidades. La incipiente estructuración poblacional detectada en este estudio no está relacionada sistemáticamente con las características biogeográficas de la costa brasileña. La compleja interacción de las fluctuaciones en el nivel del mar, las corrientes marinas, y las características reproductivas de la especie dificultan la identificación del rol específico de cada uno de estos procesos en la dinámica del flujo genético de las diferentes unidades poblacionales del mero guasa del Atlántico. Los bajos niveles generales de la diversidad genética, los valores de $\mathrm{F}_{\mathrm{ST}}$ dos a dos, y la significante estructuración poblacional entre los grupos $\left(\Phi_{\mathrm{CT}}\right)$ identificada en el presente estudio, todo refuerza el estado de peligro crítico de la especie y son inconsistentes con la existencia de una simple, población panmíctica de meros guasa de la costa brasileña. Los resultados de este estudio sugieren que, a pesar de que puede ser incipiente, la estructuración genética observada debe ser tenida en cuenta con el fin de evitar problemas potenciales, tales como la depresión exogámica, cuando se maneja poblaciones silvestres.
\end{abstract}

Palabras clave: especie en peligro crítico; flujo génico; diversidad genética; peces marinos; Océano Atlántico Oeste.

Citation/Como citar este artículo: Damasceno J.S., Siccha-Ramirez R., Morales M.J.A., Oliveira C., Torres R.A., Costa E.N., Silva-Oliveira G.C., Vallinoto M., Machado L.F., Tosta V.C., Farro A.P.C., Hostim-Silva M. 2015. Mitochondrial DNA evidences reflect an incipient population structure in Atlantic goliath grouper (Epinephelus itajara, Epinephelidae) in Brazil. Sci. Mar. 79(4): 419-429. doi: http://dx.doi.org/10.3989/scimar.04203.20A

Editor: J. Viñas.

Received: January 7, 2015. Accepted: September 15, 2015. Published: October 22, 2015.

Copyright: (C) 2015 CSIC. This is an open-access article distributed under the Creative Commons Attribution-Non Commercial Lisence (by-nc) Spain 3.0.

\section{INTRODUCTION}

The Atlantic goliath grouper Epinephelus itajara (Lichtenstein, 1822) is the largest grouper in the Atlantic Ocean, where it is found in tropical and subtropical waters ranging from the state of Florida in the USA to southern Brazil, as well as on the western coast of Africa from the Congo Republic to Senegal (Craig et al. 2012). This grouper is listed as critically endangered by the IUCN (International Union for Conservation of Nature), based on criterion A2d (IUCN 2015).

Slow growth, longevity and behavioural traits such as the tendency to form breeding groups make E. itaja$r a$ populations susceptible to fishing pressure (Bullock et al. 1992). Migration to key locations for the purposes of breeding, observed in most species of the subfamily Epinephelinae (Coleman et al. 2011), has not been fully clarified in E. itajara (Mann et al. 2008) and, in fact, both adults and juveniles exhibit location fidelity (Eklund and Schull 2001, Koenig et al. 2007). However, there is evidence based on individual markings that E. itajara breeding groups occur at specific locations and that the adults are capable of travelling long distances to areas far from the coast (Pina-Amargós and Gonzaléz-Sansón 2009).

The dispersal of pelagic larvae is correlated with connectivity among different environments and likely depends on local oceanographic patterns, the biological attributes of the larvae, and specific aspects of the reproductive behaviour of the adults, which facilitate local recruitment (Mora and Sale 2002). The long larval phase suggests a considerable dispersal capacity, which may result in a lack of stock structuring on oceanic, regional and subregional scales (Aboim et al. 2005 ). The hypothesis of highly vagile $E$. itajara larvae is supported by the presence of a broad genetic-evolutional unit along the Atlantic coast of South America
(Benevides et al. 2014). Larval retention by species with aggregated spawning may be selectively advantageous to ensure the access of larvae and juveniles to necessary resources, but a high degree of dispersal and connectivity may not necessarily ensure homogeneous gene flow (Portnoy et al. 2013).

The first molecular data on E. itajara highlighted the phylogenetic position of the species in the subfamily (Epinephelidae sensu stricto) (Craig and Hastings 2007) and the genetic features of some populations in northern Brazil, based on the mitochondrial control region (Silva-Oliveira et al. 2008). It was subsequently determined that goliath groupers in the Pacific constitute a cryptic species (E. quinquefasciatus) in comparison with the populations of the Atlantic (E. itajara), as demonstrated by their cytochrome B sequences (Craig et al. 2009). Silva-Oliveira et al. (2012), Seyoum et al. (2013) and Silva-Oliveira et al. (2014) developed specific markers for E. itajara to establish a more effective database for population studies with evolutionary models aimed specifically at the protection of the species. Torres et al. (2013) developed a molecular identification protocol for monitoring the fishing of groupers, including E. itajara, E. morio, Mycteroperca bonaci and $M$. marginata. Using simple repeat sequence markers, Benevides et al. (2014) confirmed the low degree of genetic variation in E. itajara populations from ten locations, including the Atlantic coast of South America, and revealed a strong population division in southern Brazil in comparison with populations found in the eastern and northern regions of the country.

Silva-Oliveira et al. (2008) used a mitochondrial marker to study E. itajara populations on the northern coast of Brazil, while Benevides et al. (2014) used a nuclear marker to study populations on the northern and eastern coasts. Both studies have provided important insights into the population genetics of the species. 
However, mitochondrial markers have not yet been used to investigate populations along the whole of the vast Brazilian coastline, despite the importance of data on both nuclear and mitochondrial markers for the development of management strategies for endangered species (Toews and Brelsford 2012). A recent study of E. itajara on the Brazilian coast (Giglio et al. 2014) identified local and resident breeding groups, which point to the possibility of the formation of local, temporary populations. The aim of the present study was to evaluate gene flow using a portion of the genome (mitochondrial control region) subject to more accelerated molecular evolution (Tang et al. 2006) to determine signs of heretofore unrecognized $E$. itajara population divisions. The detection of population divisions is important for conservation, as it may reveal evolutionary significant units and management units, which would facilitate genetic rescue programmes and lead to an increase in the effective population size of this species.

\section{MATERIALS AND METHODS}

\section{Sampling}

The 218 samples of E. itajara analysed in the present study were collected at six different localities: Bragança (Pará: PA) $(\mathrm{N}=10)$, Tamandaré (Pernambuco: PE) ( $\mathrm{N}=25)$, Vaza Barris (Sergipe: $\mathrm{SE})(\mathrm{N}=14)$, Caravelas (Bahia: BA) (N=50), Conceição da Barra (Espírito Santo: ES) $(\mathrm{N}=114)$ and Babitonga (Santa Catarina: SC) (N=5) (Fig. 1). The DNA was extracted from the caudal fin using the method described by Wasko et al. (2003). Each specimen was weighed and measured (total and standard lengths), marked, and then released at the capture site. This procedure was determined by the licenses issued by the Sistema de Autorização e Informação em Biodiversidade (SIS$\mathrm{BIO} / \mathrm{ICMBIO} / \mathrm{MMA}$ ) of the Brazilian government, under numbers 25088-7 (authentication code 11928433) and 15080-2 (authentication code 84636263). All the samples were conserved in $95 \%$ ethanol and stored at $-20^{\circ} \mathrm{C}$ in the Aquatic Vertebrates and Animal Genetics and Conservation laboratories at CEUNES/UFES.

Additional sequences of Atlantic goliath grouper were obtained in GenBank under numbers FJ176303 to FJ176329. These sequences refer to specimens collected in Bragança + Ajuruteua (Pará: PA) $(\mathrm{N}=92)$, called in this study by 'Bragança', Parnaíba (Piauí: PI) $(\mathrm{N}=12)$, Fortaleza (Ceará: $\mathrm{CE})(\mathrm{N}=2)$ and Natal (Rio Grande do Norte: $\mathrm{RN}$ ) (N=9) (Silva-Oliveira et al. 2008) (Table 1).

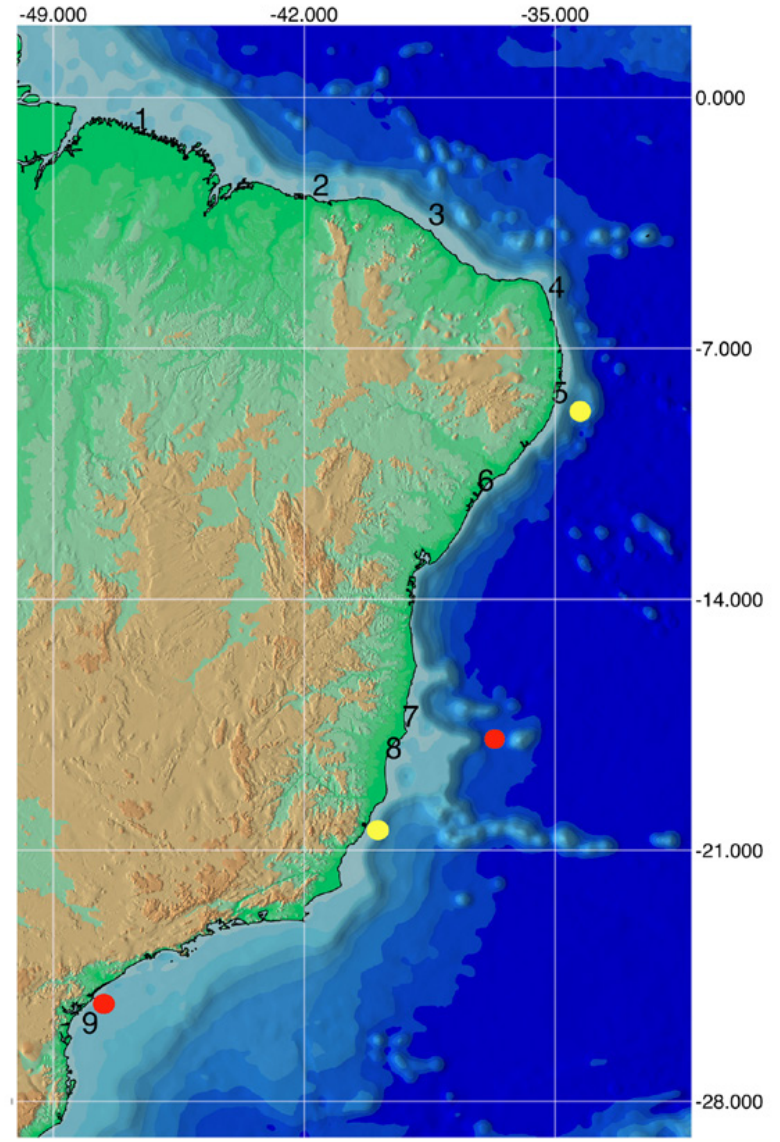

Fig. 1. - Map of locations sampled on the coast of Brazil for population genetic characterization of Atlantic goliath grouper (Epinephelus itajara) offshore Brazil. 1, Bragança; 2, Parnaíba; 3, Fortaleza; 4, Natal; 5, Tamandaré; 6, Vaza Barris; 7, Caravelas; 8, Conceição da Barra; 9, Babitonga. Red circle, site of aggregations $\geq 30$ sightings; Yellow circle, Site of aggregations 11 to 29 sightings of $E$. itajara (Giglio et al. 2014).

\section{DNA extraction, amplification and sequencing}

The DNA was extracted using the saline protocol described by Aljanabi and Martinez (1997). The control region was amplified in a total reaction volume of $12.5 \mu \mathrm{L}: 1 \mathrm{X}$ of Taq DNA polymerase buffer $(200 \mathrm{mM}$ Tris- $\mathrm{HCl}, \mathrm{pH} 8.4$, and $500 \mathrm{mM}$ of $\mathrm{KCl}$ ), $1.5 \mathrm{mM}$ of $\mathrm{MgCl}_{2}, 0.2 \mathrm{mM}$ of dNTP, 1 unit of Taq DNA polymerase enzyme buffer (PHT Phoneutria ${ }^{\circledR}$ ), $10 \mathrm{ng} / \mu \mathrm{L}$ of DNA and $0.2 \mu \mathrm{M}$ of the primers. The control region primers were L-Pro-1 (5'-ACT CTC ACC CCT AGC TCC CAA AG - 3') and H-DL-C-1 (5'- CCT GAA GTA GGA ACC AGA TGC CAG - 3') described by

Table 1. - Number $(\mathrm{N})$ of specimens of Epinephelus itajara from different locations in Brazil.

\begin{tabular}{|c|c|c|c|c|}
\hline Population Unit & Municipality (State) & $\mathrm{N}$ & Coordinates & Source \\
\hline 1 & Bragança (PA): BRA & 102 & $01^{\circ} 03^{\prime} \mathrm{S} 46^{\circ} 46^{\prime} \mathrm{W}$ & Silva-Oliveira et al. (2008) \\
\hline 2 & Parnaíba (PI): PAR & 12 & $02^{\circ} 54^{\prime} \mathrm{S} 41^{\circ} 46^{\prime} \mathrm{W}$ & Silva-Oliveira et al. (2008) \\
\hline 3 & Fortaleza (CE): FOR & 02 & $03^{\circ} 43^{\prime} \mathrm{S} 38^{\circ} 32^{\prime} \mathrm{W}$ & Silva-Oliveira et al. (2008) \\
\hline 4 & Natal (RN): NAT & 09 & $05^{\circ} 45^{\prime} \mathrm{S} 35^{\circ} 12^{\prime} \mathrm{W}$ & Silva-Oliveira et al. (2008) \\
\hline 5 & Tamandaré (PE): TAM & 25 & $08^{\circ} 41^{\prime} \mathrm{S} 35^{\circ} 06^{\prime} \mathrm{W}$ & $\begin{array}{l}\text { This study } \\
\text { The }\end{array}$ \\
\hline 6 & Vaza Barris (SE): VBS & 14 & $11^{\circ} 08^{\prime} \mathrm{S} 37^{\circ} 10^{\prime} \mathrm{W}$ & This study \\
\hline 7 & Caravelas (BA): CAR & 50 & $17^{\circ} 43^{\prime} \mathrm{S} 39^{\circ} 16^{\prime} \mathrm{W}$ & This study \\
\hline 8 & Conceição da Barra (ES): CBR & 111 & $18^{\circ} 36^{\prime} \mathrm{S} 39^{\circ} 44^{\prime} \mathrm{W}$ & This study \\
\hline 9 & Babitonga (SC): BAB & 5 & $26^{\circ} 16^{\prime} \mathrm{S} 48^{\circ} 42^{\prime} \mathrm{W}$ & This study \\
\hline
\end{tabular}


Ostellari et al. (1996). The parameters for the polymerase chain (PCR) reactions was $95^{\circ} \mathrm{C}$ for $5 \mathrm{~min}, 34$ cycles of denaturation at $95^{\circ} \mathrm{C}$ for $1 \mathrm{~min}$, hybridization at $50^{\circ} \mathrm{C}$ for $1 \mathrm{~min}$ and extension at $68^{\circ} \mathrm{C}$ for $1 \mathrm{~min}$, followed by a final extension at $68^{\circ} \mathrm{C}$ for 5 minutes.

The sequencing reaction (Sanger et al. 1977) was prepared for a final volume of $7 \mu \mathrm{L}$ with $0.35 \mu \mathrm{L}$ of primer, $1.05 \mu \mathrm{L}$ of BigDye ${ }^{\circledR}$ Terminator buffer v3.1 5X for sequencing, $0.7 \mu \mathrm{L}$ of BigDye ${ }^{\circledR}$ Terminator v3.1 Cycle and $1.0 \mu \mathrm{L}$ of DNA. The reaction was placed for sequencing PCR with incubation at $96^{\circ} \mathrm{C}$ for $2 \mathrm{~min}$, followed by 35 cycles of denaturation at $96^{\circ} \mathrm{C}$ for $30 \mathrm{~s}$, annealing at $54^{\circ} \mathrm{C}$ for $15 \mathrm{~s}$ and extension at $60^{\circ} \mathrm{C}$ for 4 min. The amplified fragments were visualized under a blue light transilluminator in $1 \%$ agar gel in $1 \mathrm{X}$ TAE (Tri-Acetate EDTA) with GelGreen $\left(\right.$ Biotium $\left.{ }^{\circledR}\right)$. The sequenced DNA fragments were read in an ABI Prism 3130 (Applied Biosystems) automatic sequencer.

\section{Alignment}

The sequences were analysed and edited using the Geneious program v.4.8.5 (Drummond et al. 2009) (http://www.geneious.com/). Mitochondrial sequences of the control region of Epinephelus itajara were validated with a search of the GenBank database for similar sequences (http://www.ncbi.nih.gov/BLAST). All sequences were aligned using the Muscle program (www.ebi.ac.uk/Tools/msa/muscle/) (Edgar 2004). The sequences of the mtDNA control region of this study were deposited in GenBank under accession numbers KP331716 to KP331745.

\section{Molecular analyses and Analysis of structuring and diversity}

Nucleotide composition and intra-species genetic distances were estimated using the two-parameter Kimura model with 10000 bootstrap pseudoreplicates with the aid of the Mega program v.5.2 (Tamura et al. 2011).

Nine a priori sampling units were defined according to geographical criteria: Bragança, Parnaíba, Fortaleza, Natal, Tamandaré, Vaza Barris, Caravelas, Conceição da Barra and Babitonga. For the analyses, the samples were grouped for each unit using the DnaSP v.5 program (Librado and Rozas 2009). The units of Fortaleza $(\mathrm{N}=2)$ and Babitonga $(\mathrm{N}=5)$ were not considered for analyses of population structure due to the low number of samples. Intra-population diversity was analysed by estimating the haplotype diversity (h) and nucleotide diversity $(\pi)$ in Arlequin v.3.5 (Excoffier et al. 2005). Genetic differentiation between each pair of sampling groups was tested using the $F_{S T}$ index (Excoffier et al. 2005). We applied a simulated grouping approach in order to maximize the variance among the population units, using spatial analysis of molecular variance (SAMOVA) software to test for possible statistical deviations consistent with population structuring among the sampling units. Population structuring is indicated by high and significant $\Phi_{\mathrm{CT}}$ values $(\mathrm{p}<0.05)$. Population analyses were run in the SAMOVA v.2.0 program (Dupanloup et al. 2002).

The relationship among haplotypes was established through the Haploviewer program (http://www.broad. mit.edu/mpg/haploview/), which provides computation of linkage disequilibrium (LD) statistics and population haplotype patterns (Barrett et al. 2005).

The "isolation by distance" model was analysed using the Mantel test (BioEstat v.5.3; Ayres et al. 2007) among matrices of the log-transformed genetic divergence and geographic distances between population units. The hypothesis of the neutrality of mutations over time was tested using Tajima's D and Fu's Fs with 1000 permutations, run in Arlequin v.3.5.

\section{RESULTS}

\section{Genetic variability}

The control region was sequenced in 330 individuals (338 bp). A total of $319 \mathrm{bps}$ were conserved sites, 19 were variable and 12 were informative for the parsimony analyses. Nucleotide frequencies were $\mathrm{T}=0.331$, $\mathrm{C}=0.145, \mathrm{~A}=0.316$ and $\mathrm{G}=0.208$. The overall haplotype diversity of the control region was moderate, with the lowest values being found in the Babitonga, Caravelas and Parnaíba populations and the highest ones in the Tamandaré, Conceição da Barra, Bragança, Vaza Barris and Natal populations (range across all populations: 0.400 to 0.861 ). Total haplotype diversity was 0.757 . However, nucleotide diversity was low in all population units, ranging from 0.001 to 0.005 (Table 2).

The results indicate moderate levels of haplotype diversity in Bragança (0.806), Natal (0.861), Vaza Barris (0.846), Conceição da Barra (0.798) and Tamandaré (0.710), and the lowest levels in Parnaíba (0.530), Caravelas (0.516) and Babitonga (0.400). While nucleotide diversity was extremely low (0.001 to 0.005$)$ for all populations, the highest values were recorded for TAM, VBS and CBR, and much lower ones for Bragança, Parnaíba and Babitonga (Table 2).

\section{Patterns of genetic differentiation}

The pairwise $\mathrm{F}_{\mathrm{ST}}$ values for comparisons between populations varied considerably, between 0.005 and 0.833. However, Caravelas (Bahia) was significantly different from six populations: Bragança, Parnaíba, Fortaleza, Natal, Vaza Barris, and Conceição da Barra (Table 3). No significant correlation was found between the genetic divergence and genetic distance of the population units based on the control region marker $(r=0.0501 ; p=0.7719)$, indicating that geographic distance does not explain the genetic divergence among the Atlantic goliath grouper population units sampled along the coast of Brazil (Fig. 1).

The SAMOVA indicated incipient genetic structuring among the Brazilian populations $\left(\Phi_{\mathrm{ST}}=0.083\right.$ to $0.121 ; \mathrm{p}<0.001)$, with three to five distinct populations (k) being observed (Table 4), and significant population structuring $\left(\Phi_{\mathrm{CT}}=0.090\right.$ to $\left.0.083 ; \mathrm{p}<0.05\right)$. In three different groupings $(\mathrm{k} 3, \mathrm{k} 4$, and $\mathrm{k} 5)$, the Parnaíba and 
Table 2. - Intra-population haplotype and nucleotide diversity in sequenced segment of control region. *, $\mathrm{p}<0.02$.

\begin{tabular}{lcccccc}
\hline \multirow{2}{*}{ Population unit } & \multicolumn{2}{c}{ Haplotypes } & \multirow{2}{*}{ Haplotype diversity $(\mathrm{h})$} & \multirow{2}{*}{ Nucleotide diversity (p) } & \multirow{2}{*}{ Tajima's D } & \multirow{2}{*}{ Fu's Fs } \\
\hline 1. Bragança & 23 & 12 & $0.806 \pm 0.034$ & $0.001 \pm 0.001$ & -1.278 & $-12.504 *$ \\
2. Parnaíba & 2 & - & $0.530 \pm 0.076$ & $0.001 \pm 0.001$ & 1.381 & 1.152 \\
3. Fortaleza & 1 & - & $0.000 \pm 0.000$ & $0.000 \pm 0.000$ & 0.000 & 0.000 \\
4. Natal & 5 & 2 & $0.861 \pm 0.087$ & $0.002 \pm 0.002$ & -0.551 & -1.593 \\
5. Tamandaré & 8 & 5 & $0.710 \pm 0.087$ & $0.004 \pm 0.003$ & -0.979 & -2.284 \\
6. Vaza Barris & 6 & 2 & $0.846 \pm 0.061$ & $0.005 \pm 0.003$ & 0.191 & -0.238 \\
7. Caravelas & 6 & 2 & $0.516 \pm 0.077$ & $0.002 \pm 0.002$ & -0.980 & -1.786 \\
8. Conceição da Barra & 12 & 3 & $0.798 \pm 0.025$ & $0.005 \pm 0.003$ & -0.241 & -1.970 \\
9. Babitonga & 2 & 1 & $0.400 \pm 0.237$ & $0.001 \pm 0.001$ & -0.816 & 0.090 \\
\hline
\end{tabular}

Table 3. - Pairwise $\mathrm{F}_{\mathrm{ST}}$ (below diagonal) and geographic distance data (above diagonal) for population units of Epinephelus itajara along coast of Brazil after Bonferoni correction ( $\mathrm{p}=0.0056$ ); BRA, Bragança; PAR, Parnaíba; NAT, Natal; TAM, Tamandaré; VBS, Vaza Barris; CAR, Caravelas; CBR, Conceição da Barra. *, p<0.05.

\begin{tabular}{|c|c|c|c|c|c|c|c|c|c|}
\hline Population unit & 1.BRA & 2.PAR & 3.FOR & 4.NAT & 5.TAM & 6.VBS & 7.CAR & 8.CBR & 9.BAB \\
\hline 1. BRA & & $1072 *$ & $1482^{*}$ & 1981 & $2351 *$ & 2721 & $3588^{*}$ & $3709 *$ & 5161 \\
\hline 2. PAR & $0.322 *$ & & $410^{*}$ & $909 *$ & $1279 *$ & $1649 *$ & $2516^{*}$ & $2637 *$ & $4089^{*}$ \\
\hline 3. FOR & $0.561 *$ & $0.832 *$ & & $499 *$ & $869 *$ & $1239 *$ & $2106^{*}$ & 2227 & $3679 *$ \\
\hline 4. NAT & 0.121 & $0.264 *$ & $0.617 *$ & & 370 & 740 & $1607 *$ & 1728 & 3180 \\
\hline 5. TAM & $0.044 *$ & $0.185^{*}$ & $0.571 *$ & 0.029 & & 370 & 1237 & 1358 & 2810 \\
\hline 6. VBS & 0.009 & $0.267 *$ & $0.522 *$ & 0.021 & 0.010 & & $867 *$ & 988 & 2440 \\
\hline 7. CAR & $0.195 *$ & $0.259^{*}$ & $0.707 *$ & $0.010 *$ & 0.043 & $0.151^{*}$ & & $121^{*}$ & 1573 \\
\hline 8. CBR & $0.032 *$ & $0.229 *$ & 0.522 & 0.056 & 0.013 & 0.005 & $0.082 *$ & & 1452 \\
\hline 9. $\mathrm{BAB}$ & 0.251 & $0.406^{*}$ & $0.833^{*}$ & 0.153 & 0.090 & 0.206 & -0.048 & 0.130 & \\
\hline
\end{tabular}

Table 4. - SAMOVA of control region marker in Epinephelus itajara demonstrating four population groups along the Brazilian coast with significant $\Phi_{\mathrm{CT}}$ results. BRA, Bragança; PAR, Parnaíba; NAT, Natal; TAM, Tamandaré; VBS, Vaza Barris; CAR, Caravelas; CBR, Conceição

\begin{tabular}{|c|c|c|c|c|c|}
\hline $\begin{array}{c}\mathrm{N}^{\circ} \text { of } \\
\text { groups (k) }\end{array}$ & Comparisons & Source of Variations & F statistic & $\begin{array}{l}\text { Percentage of } \\
\text { variation }\end{array}$ & p-value \\
\hline 3 & $(\mathrm{PAR}) \times(\mathrm{CAR}) \times(\mathrm{BRA}, \mathrm{NAT}, \mathrm{TAM}, \mathrm{VBS}, \mathrm{CBR})$ & $\begin{array}{l}\text { Among groups } \\
\text { Among population within groups } \\
\text { Within populations }\end{array}$ & $\begin{array}{l}\Phi_{\mathrm{CT}}=0.090 \\
\Phi_{\mathrm{SC}}=0.034 \\
\Phi_{\mathrm{ST}}=0.121\end{array}$ & $\begin{array}{c}9.00 \\
3.17 \\
87.83\end{array}$ & $\begin{array}{l}0.047 \\
0.010 \\
0.000\end{array}$ \\
\hline 4 & $\begin{array}{c}(\mathrm{PAR}) \times(\mathrm{NAT}) \times(\mathrm{CAR}) \times(\mathrm{BRA}, \mathrm{TAM}, \mathrm{VBS}, \\
\mathrm{CBR})\end{array}$ & $\begin{array}{c}\text { Among groups } \\
\text { Among population within groups } \\
\text { Within populations }\end{array}$ & $\begin{array}{l}\Phi_{\mathrm{CT}}=0.087 \\
\Phi_{\mathrm{SC}}=0.030 \\
\Phi_{\mathrm{ST}}=0.115\end{array}$ & $\begin{array}{l}8.78 \\
2.80 \\
88.42\end{array}$ & $\begin{array}{l}0.030 \\
0.019 \\
0.000\end{array}$ \\
\hline 5 & 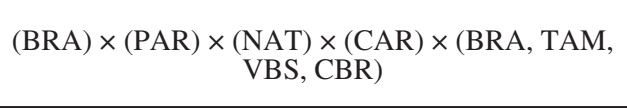 & $\begin{array}{l}\text { Among groups } \\
\text { Among population within groups } \\
\text { Within populations }\end{array}$ & $\begin{array}{l}\Phi_{\mathrm{CT}}=0.083 \\
\Phi_{\mathrm{SC}}=0.000 \\
\Phi_{\mathrm{ST}}=0.083\end{array}$ & $\begin{array}{l}8.28 \\
0.06 \\
91.66\end{array}$ & $\begin{array}{l}0.029 \\
0.431 \\
0.000\end{array}$ \\
\hline
\end{tabular}

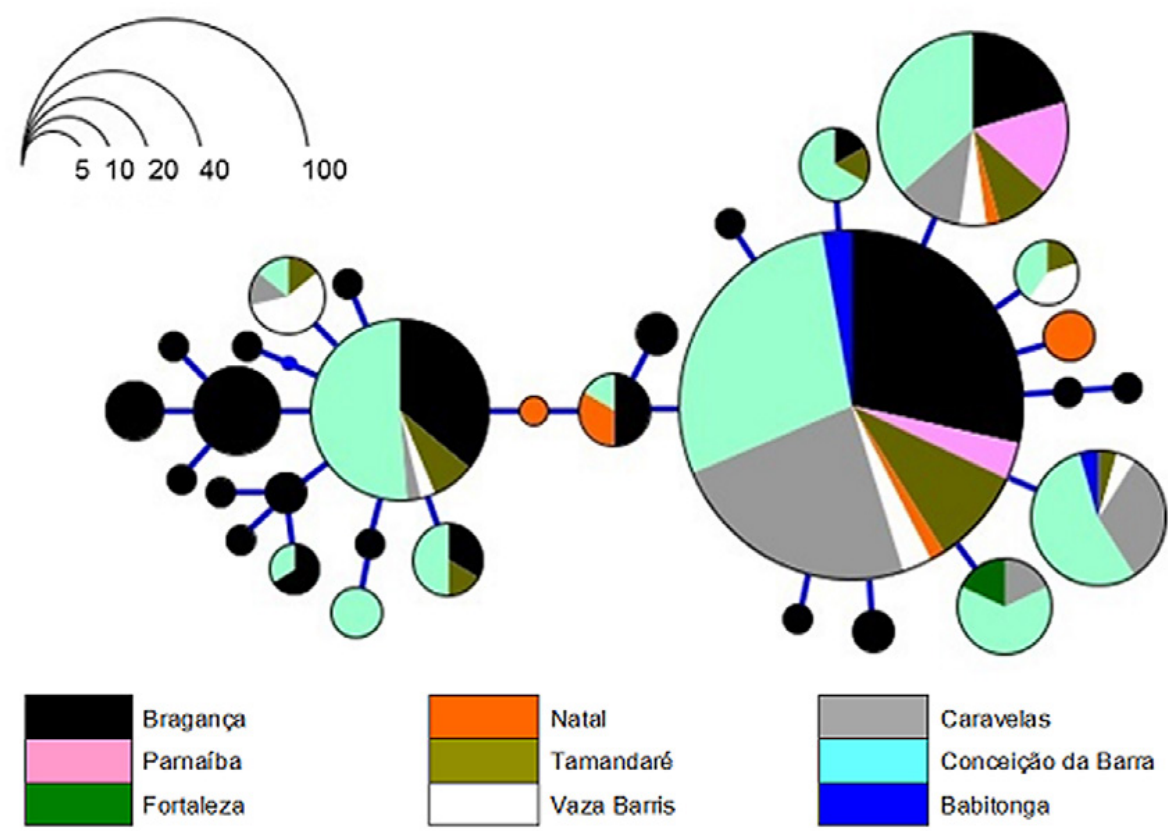

Fig. 2. - Haplotype network of control region of mtDNA for distant Epinephelus itajara population units on coast of Brazil. Continuous line: one mutational step. Blue circle: adding more mutational steps. 
Table 5. - Distribution and frequency of haplotypes generated from fragment of mtDNA control region in E. itajara population units on coast of Brazil; BRA, Bragança; PAR, Parnaíba; FOR, Fortaleza; NAT, Natal; TAM, Tamandaré; VBS, Vaza Barris; CAR, Caravelas; CBR,

\begin{tabular}{|c|c|c|c|c|c|c|c|c|c|c|c|}
\hline Haplotypes & $\mathrm{N}$ & BRA & PAR & FOR & NAT & TAM & VBS & CAR & CBR & $\mathrm{BAB}$ & Accession numbers \\
\hline Hap_1 & 6 & 3 & & & 2 & & & & 1 & & KP331716 \\
\hline Hap_2 & 9 & 9 & & & & & & & & & KP331717 \\
\hline Hap_3 & 39 & 14 & & & & 3 & 1 & 1 & 20 & & KP331718 \\
\hline Hap_4 & 4 & 4 & & & & & & & & & KP331719 \\
\hline Hap_5 & 1 & 1 & & & & & & & & & KP331720 \\
\hline Hap_6 & 1 & 1 & & & & & & & & & KP331721 \\
\hline Hap_7 & 1 & 1 & & & & & & & & & KP331722 \\
\hline Hap_8 & 6 & 1 & & & & 1 & & & 4 & & KP331723 \\
\hline Hap_9 & 1 & 1 & & & & & & & & & KP331724 \\
\hline Hap_10 & 2 & 2 & & & & & & & & & KP331725 \\
\hline Hap_11 & 1 & 1 & & & & & & & & & KP331726 \\
\hline Hap_12 & 1 & 1 & & & & & & & & & KP331727 \\
\hline Hap_13 & 3 & 2 & & & & & & & 1 & & KP331728 \\
\hline Hap_14 & 2 & 2 & & & & & & & & & KP331729 \\
\hline Hap_15 & 1 & 1 & & & & & & & & & KP331730 \\
\hline Hap_16 & 1 & 1 & & & & & & & & & KP331731 \\
\hline Hap_17 & 6 & 2 & & & & 1 & & & 3 & & KP331732 \\
\hline Hap_18 & 1 & 1 & & & & & & & & & KP331733 \\
\hline Hap_19 & 144 & 41 & 5 & & 2 & 13 & 4 & 34 & 41 & 4 & KP331734 \\
\hline Hap_20 & 1 & 1 & & & & & & & & & KP331735 \\
\hline Hap_21 & 1 & 1 & & & & & & & & & KP331736 \\
\hline Hap_22 & 2 & 2 & & & & & & & & & KP331737 \\
\hline Hap_23 & 44 & 9 & 7 & & 1 & 4 & 2 & 5 & 16 & & KP331738 \\
\hline Hap_24 & 11 & & & 2 & & & & 2 & 7 & & KP331739 \\
\hline Hap_25 & 7 & & & & & 1 & 4 & 1 & 1 & & KP331740 \\
\hline Hap_26 & 5 & & & & & 1 & 2 & & 2 & & KP331741 \\
\hline Hap_27 & 22 & & & & & 1 & 1 & 7 & 12 & 1 & KP331742 \\
\hline Hap_28 & 3 & & & & 3 & & & & & & KP331743 \\
\hline Hap_29 & 1 & & & & 1 & & & & & & KP331744 \\
\hline Hap_30 & 3 & & & & & & & & 3 & & KP331745 \\
\hline
\end{tabular}

Caravelas remained structured in comparison with all other Brazilian localities (Table 4). Considering the values of the pairwise $F_{S T}$ and the $\Phi_{\mathrm{CT}}$ of the SAMOVA, three populations were defined: 1) Parnaíba; 2) Caravelas; 3) Bragança + Tamandaré + Vaza Barris + Conceição da Barra.

A total of 30 haplotypes were identified, none of which was present in all locations. However, haplotypes 19 and 23 were widely distributed and common in all population units, except those for which the samples were small, i.e. Fortaleza and Babitonga (Fig. 2).

The Bragança, Conceição da Barra, and Tamandaré units showed the greatest number of haplotypes (76.7\%, $40.0 \%$ and $26.7 \%$ of the total, respectively). Overall, 19 (63\%) of the haplotypes were identified in a single unit, of which 12 were rare. The Bragança (12 haplotypes) and Tamandaré (5 haplotypes) units had the greatest number of exclusive haplotypes (56\%) in comparison with other populations (Fig. 2). However, the results demonstrate the sharing of haplotypes among all units, even the most geographically distant ones (Table 5).

\section{Demographic history and neutrality}

Tajima's D values were negative for the majority of E. itajara population units, but not statistically significant. Likewise, Tajima's D for the grouped units was non-significant $(D=-1.269 ; p>0.10)$, so the hypothesis of neutrality in the E. itajara populations of the Brazilian coast was rejected. The results of Fu's Fs test based on the distribution of haplotypes also demonstrated non-significant negative values for all population units, except Bragança (Table 2).

\section{DISCUSSION}

\section{Genetic variation}

The analysis of the mitochondrial control region revealed moderate to low genetic diversity (Grant and Bowen 1998, Silva-Oliveira et al. 2008) in the Atlantic goliath grouper populations on the coast of Brazil, as demonstrated by the haplotype diversity (h) and very low nucleotide diversity $(\pi)$ values. These genetic diversity values differ from the high values reported by Rivera et al. (2004) for E. quernus in Hawaii (USA) and by Souza et al. (2015) for Cephalopholis fulva (Epinephelidae) on the Brazilian coast, although they are similar to the values reported for other species of reef fish (Zhang et al. 2006, Hobbs et al. 2013). The reduced genetic diversity of the Atlantic goliath grouper has been related to overfishing and the loss of habitats (Silva-Oliveira et al. 2008), and the accentuated decline of the populations of this species throughout its area of distribution in recent years (McClenachan 2009, Coleman and Koenig 2010) may exert a negative influence on its genetic diversity in the near future, further underscoring its status as a critically endangered species. Low genetic diversity in E. itajara has been suggested in microsatellite loci (Seyoum et al. 2013), segments of immunological genes (Silva-Oliveira et al. 2014), and nuclear markers anchored in microsatellite regions (Benevides et al. 2014), further reinforcing the threatened status of the species on the Brazilian coast. 
The neutrality tests (Tajima's D and Fu's Fs) in the present study lend support to the hypothesis of a low degree of genetic variation. Based on Tajima's D and Fu's Fs, there is no evidence that any of the Atlantic goliath grouper populations along the coast of Brazil are in a process of demographic or spatial expansion. Tajima's D for the pooled data of all units also does not suggest population expansion $(\mathrm{D}=-1.269$; $\mathrm{p}>0.10)$. However, Fu's Fs was significant ( $F s=-12.505 ; \mathrm{p}<0.02)$ for the Bragança (Pará) population, indicating population expansion. Mangroves are important nursery areas for E. itajara (Frias-Torres 2006, Koenig et al. 2007). Recent events, such as the Holocene fluctuations in sea level with the associated changes in the sedimentation patterns of the Amazon basin, modified the distribution of mangrove ecosystems on the northern coast of Brazil (Cohen et al. 2005). Furthermore, human impacts on these environments over the past few centuries may have contributed to the loss of habitats in this region (Behling et al. 2001), which is reflected in the low genetic diversity observed in the present study.

\section{Population structuring}

The amplitude of the pairwise genetic differentiation $\left(\mathrm{F}_{\mathrm{ST}}\right)$ and the comparison of three population groups (1. Parnaíba 2. Caravelas 3. Bragança, Natal, Tamandaré, Vaza Barris and Conceição da Barra) indicate the existence of significant structuring $\left(\Phi_{\mathrm{CT}}=0.09\right.$, $\mathrm{p}<0.05)$ in the E. itajara populations on the Brazilian coast. These results indicate that the gene flow on the Brazilian coast is discontinuous and not totally homogeneous, and no evidence was found of any systematic relationship with geographic patterns. According to Allendorf and Phelps (1981), reduced levels of gene flow can homogenize the genetic makeup of populations, and even a small amount of gene flow would be sufficient to annul differences in the frequency of alleles among populations (Palumbi 2003). Thus, genetic structuring among the geographically close population units analysed in the present study indicates the occurrence of certain limitations on larval dispersal. A lack of any systematic relationship between genetic patterns and geographic distribution has also been found in genetic studies of reef fish on the Brazilian coast, including Ocyurus chrysurus (Lutjanidae) (Vasconcellos et al. 2008) and Cephalopholis fulva (Epinephelidae) (Souza et al. 2015). Significant genetic structuring, with relatively reduced variation between populations $\left(\Phi_{\mathrm{CT}}\right)$, has been detected in a number of marine fishes (Zhang et al. 2006, Cunha et al. 2014) and may indicate the occurrence of intermittent gene flow (Hébert et al. 2000) between the coastal areas analysed in this study.

The greater genetic differentiation between the Caravelas sample and both distant (Bragança and Parnaíba) and adjacent (Vaza Barris and Conceição da Barra) populations may be accounted for by the transgression and regression events that occurred on the Brazilian coast during the Quaternary (Andrade et al. 2003), which provoked fluctuations in sea levels, in particular over the past 120000 years (Suguio et al. 1985, Bittencourt et al. 2000). These oscillations probably hampered the colonization process and may have resulted in the formation of barriers to the dispersal of pelagic larvae in the region of the Abrolhos Ridge in Bahia, in particular on the inner continental shelf through the formation of effective hydrodynamic and geological barriers (Leipe 1999) and the reversion of currents (Teixeira et al. 2013), which would have retained the larvae at the mouth of the Caravelas River, in southern Bahia. Interactions between small (1-10 individuals) resident breeding groups (Giglio et al. 2014) in areas favourable to larval retention may result in reduced gene flow and greater differentiation among populations.

In addition to the fluctuations in sea level, the Parnaíba region is affected by the Intertropical Convergence zone (ITCZ). Between 40-8 thousand years ago (kya), the ITCZ shifted towards the northern coast of Brazil, affecting the surface temperature of the sea and wind intensity, creating semi-arid conditions in northeastern Brazil. These conditions were interrupted by short cycles of higher precipitation, and one long cycle between 15-11 kya, when the ITCZ migrated between the equator and northeastern Brazil (Moura and Shukla 1981, Arz et al. 1998, Behling et al. 2000). The semi-arid conditions are reflected in the region's coastal vegetation, especially between Piauí $\left(2^{\circ} \mathrm{S}\right)$ and Rio Grande do Norte $\left(5^{\circ} \mathrm{S}\right)$. Here, alluvial deposits are limited to a few small areas, due to the exposure of the local rivers to wave energy, and stratigraphic data indicate that mangroves, especially Rhizophora, were established only at the beginning of the Holocene and were probably rare or absent during most of the Last Glacial Maximum (Behling et al. 2000). Even then, mangrove forests, which are considered to be essential nursery areas for Epinephelus itajara (Koenig et al. 2007), have a limited distribution in this region due to the scarcity of bodies of freshwater, prolonged droughts and high salinity, which restricts the development of these plants (Schaeffer-Novelli et al. 1990). These unique local conditions may have a fundamental influence on the population dynamics of E. itajara, given that the density of juvenile individuals may be affected by the structural complexity of the mangrove (FriasTorres 2006) and the positive correlation between the abundance of adult groupers and the extension of adjacent areas of mangrove (Sadovy and Eklund 1999).

The results of this study showed that haplotypes were widely shared, although the SAMOVA identified significant $\Phi_{\mathrm{ST}}$ values, which indicate a certain amount of population differentiation (Wright 1951) based on restrictions to gene flow. However, this genetic structuring-indicated by the $\Phi_{\mathrm{ST}}$ value-is much lower than that found in other groupers, such as Epinephelus labriformis $\left(\mathrm{F}_{\mathrm{ST}} \leq 0.661, \mathrm{p}=0.001\right)$ (Craig et al. 2006) and E. akaara $\left(\mathrm{F}_{\mathrm{ST}} \leq 0.379, \mathrm{p}<0.001\right)$ (Chen et al. 2008), although the population structure is similar to that found in other species of reef fish (Zhang et al. 2006, Drew and Barber 2012, Cunha et al. 2014). Silva-Oliveira et al. (2008) found significant genetic differentiation in pairwise $\mathrm{F}_{\mathrm{ST}}$ values for $E$. itajara between Parnaíba and both Bragança and Natal, but did not detect structuring between Bragança and Natal. 
The significant differences in $\mathrm{F}_{\mathrm{ST}}$ and the complex haplotype network found for the Bragança, Parnaíba, Caravelas and Conceição da Barra population units indicate that these locations are not isolated. However, the dispersal of larvae or adults may be occasional, with a lower degree of genetic exchange than that required to completely homogenize the population, possibly due to the existence of a barrier to gene flow, which may influence the degree of genetic differentiation among localities (Aboim et al. 2005). This barrier does not appear to avoid gene flow completely, given the presence of shared haplotypes among these population units. Castro et al. (2007) concluded that the sharing of haplotypes between the farthest geographic extremes of a species' range is consistent with potential migration among oceanic basins that does not independently alter the size of the different groups. Despite the small sample size for the southernmost population, at Babitonga (Santa Catarina) the common haplotypes are shared with other population units; this population is not isolated from the others and is characterized by reduced genetic diversity. This finding differs from that of Benevides et al. (2014), who used a nuclear marker. This incongruent evidence might suggest possible phenomena of sex-biased demography such as male/ female phylopatry in the region.

The circulation patterns of the Brazil Current and North Brazil Current in the South Atlantic (Soutelino et al. 2013), sedimentation events on the coastal plain that caused fluctuations in the sea level during the Last Glacial Maximum at the beginning of the Holocene (Andrade et al. 2003), and the effects of the Intertropical Convergence Zone at low latitudes (Zabel et al. 2003) may all have influenced the distribution of the species in coastal environments, resulting in asynchrony in the process of population expansion in different geographic areas (Souza et al. 2015). Regional and local oceanic circulation patterns (Teixeira et al. 2013) may also play an important role in the dispersal of eggs, as well as the recruitment of larvae and juveniles (Nonaka et al. 2000). These factors may also have determined the different levels of habitat complexity observed along the coast (Arz et al. 1998), which play an important role in the selectivity of coastal marine organisms. The modifications in the availability of habitats caused by these events induce demographic reductions and expansions that alter the connectivity and distribution of populations among the different geographic regions (Cunha et al. 2014). However, these factors have not been evaluated adequately for the understanding of the role of these events as a biogeographical filter for the Atlantic goliath grouper on the coast of Brazil.

The population structure found in the present study indicates limited gene flow, and although the small sample size may also have been important here, the size of the samples analysed in the present study was similar to that used in the studies of Silva-Oliveira et al. (2008) and Benevides et al. (2014). These incongruities may be clarified by the investigation of additional molecular markers and further research into the biology and ecology of E. itajara.
This reduced mitochondrial diversity may be related to the faster genetic drift in these haploid genes, inherited maternally, in comparison with the diploid, biparental nuclear genes (Palumbi and Bader 1994). In this case, the apparent incongruities between the mitochondrial data recorded in the present study and the results for the nuclear markers presented by Benevides et al. (2014) may be the result of demographic events, as mentioned above. As mitochondrial genes generally have higher mutation rates, due to genetic drift (Ingvarsson 2004), the mitochondrial control region will evolve more rapidly than the SNPs of the nuclear genome (Pesole et al. 1999, Kumar and Subramanian 2002) and the AMOVA demonstrated a greater degree of subdivision in comparison with the nuclear DNA ( Ji et al. 2011). Further studies of additional markers may help clarify these uncertainties.

\section{Genetic insights for conservation}

The data on the haplotypes shared among the population units of the Atlantic goliath grouper along the coast of Brazil emphasize the importance of regional haplotype richness for the genetic diversity of the species. Local impacts can have negative effects on the genetic conservation due to this sharing of haplotypes, which may extend throughout the geographic distribution of E. itajara.

The moderate haplotype diversity and extremely low degree of nucleotide diversity suggest the random fixation of variation and possible genetic drift in the study region, as a consequence of population depression resulting from founder effects or bottleneck events. However, the ample genetic diversity found among population units $(0.400-0.861)$ in the present study indicate that the effects of these events have varied considerably among the different regions, in turn reinforcing the need for the application of conservation measures in priority areas with the main focus on financial limitations.

The results of this study indicate low levels of genetic diversity, primarily in the populations from Parnaíba (Piauí) and Caravelas (southern Bahia). Ceará (Fortaleza) and Babitonga (Santa Catarina) also showed low values, although the sample size was prohibitively low in these cases. The $\Phi_{\mathrm{ST}}$ and $\mathrm{F}_{\mathrm{ST}}$ values also indicate the genetic differentiation of these populations in relation to the others located along the Brazilian coast. It is important to note, however, that few genetic data are available for the populations from the coast of southern Brazil between Conceição da Barra (Espírito Santo) and Babitonga (Santa Catarina). These populations may be problematic, given the unique geological and oceanographic characteristics of this region, which may cause different patterns of genetic diversity and gene flow in this region. Nevertheless, it does not appear reasonable to assume that the Atlantic goliath grouper of the Brazilian coast is in a state of panmixia, considering the levels of pairwise genetic differentiation found in the present study $\left(\mathrm{F}_{\mathrm{ST}}\right)$ and the significant differences found among population groups $\left(\Phi_{\mathrm{CT}}\right)$. 
Based on the findings of the present study, and the critically endangered status of the species, the current ban on the harvesting of the Atlantic goliath grouper should be maintained, considering 1) the variation found in the genetic diversity of the subpopulations located along the Brazilian coast, indicating that they have suffered differing degrees of impact and threat;2) the very low level of nucleotide diversity, which suggests a greatly reduced effective population size and indicates that overfishing and habitat destruction in recent decades may have had negative genetic effects for future generations; 3 ) the distinct findings for the mitochondrial and nuclear markers, which reinforce the need for analysis of additional molecular markers (i.e. Msats and MHC genes); and 4) the lack of data from some regions of the Brazilian coast, which may be important for understanding the dynamics of the population as a whole. The conservation of the Atlantic goliath grouper will depend on political efforts for the creation of coastal protection areas, especially in mangroves and breeding grounds, and the participation of local communities in the decision-making process.

\section{ACKNOWLEDGEMENTS}

The authors are grateful to the Coordenação de Aperfeiçoamento de Pessoal de Nível Superior (CAPES), the Fundação de Amparo à Pesquisa do Estado de São Paulo (FAPESP), the Fundação de Amparo à Pesquisa do Espírito Santo (FAPES), the Projeto Meros do Brasil, which is supported by Petrobrás S.A. (through the Programa Petrobrás Ambiental), and Transpetro Transportes S.A. for financial support. R.A. Torres is especially grateful to $\mathrm{CNPq}$ for the research fellowship provided (Grant Numbers 306099/2011-0 and 301208/2012-3).

\section{REFERENCES}

Aboim M.A., Menezes G.M., Schlitt T., et al. 2005. Genetic structure and history of populations of the deep-sea fish Helicolenus dactylopterus (Delaroche, 1809) inferred from mtDNA sequence analysis. Mol. Ecol. 14: 1343-1354. http://dx.doi.org/10.1111/j.1365-294X.2005.02518.x

Aljanabi S.M., Martinez I. 1997. Universal and rapid salt-extraction of high quality genomic DNA for PCR-based techniques. Nucleic Acids Res. 25: 4692-4693. http://dx.doi.org/10.1093/nar/25.22.4692

Allendorf F.W., Phelps S.R. 1981. Use of allelic frequencies to describe population structure. Can. J. Fish Aquat. Sci. 38: 1507-1514. http://dx.doi.org/10.1139/f81-203

Andrade A.C.S., Dominguez J.M.L., Martin L., et al. 2003. Quaternary evolution of the Caravelas strandplain - Southern Bahia State-Brazil. An. Acad. Bras. Ciênc. 75: 357-382. http://dx.doi.org/10.1590/S0001-37652003000300008

Arz H.W., Pätzold J., Wefer G. 1998. Correlated millennial-scale changes in surface hydrography and terrigenous sediment yield inferred from last-glacial marine deposits off northeastern Brazil. Quat. Res. 50: 157-166. http://dx.doi.org/10.1006/qres.1998.1992

Ayres M., Ayres Jr. M., Ayres D.L., et al. 2007. BioEstat. Versão 5.3, Sociedade Civil Mamirauá, MCT - CNPq, Belém, Pará, Brasil.

Barrett J.C., Fry B., Maller J., et al. 2005. Haploview: analysis and visualization of LD and haplotype maps. Bioinformatics 21: 263-265. http://dx.doi.org/10.1093/bioinformatics/bth457

Behling H., Arz H.W., Pätzold J., et al. 2000. Late Quaternary vegetational and climate dynamics in northeastern Brazil, inferences from marine core GeoB 3104-1. Quat. Sci. Rev. 19: 981-994. http://dx.doi.org/10.1016/S0277-3791(99)00046-3

Behling H., Cohen M.C.L., Lara R.J. 2001. Studies on Holocene mangrove ecosystem dynamics of the Bragança Peninsula in north-eastern Pará, Brazil. Palaeogeogr. Palaeocl. Palaeoecol. 167: $225-242$ http://dx.doi.org/10.1016/S0031-0182(00)00239-X

Benevides E.A., Vallinoto M., Filho A.F., et al. 2014. When physical oceanography meets population genetics: the case study of the genetic/evolutionary discontinuity in the endangered Goliath grouper (Epinephelus itajara; Perciformes: Epinephelidae) with comments on the conservation of the species. Biochem. Sys. Ecol. 56: 255-266. http://dx.doi.org/10.1016/j.bse.2014.06.004

Bittencourt A.C.S.P., Dominguez J.M.L., Martin L., et al. 2000. Patterns of sediment dispersion coastwise the State of BahiaBrazil. An. Acad. Bras. Cienc. 72: 21-33. http://dx.doi.org/10.1590/S0001-37652000000200012

Bullock L.H., Murphy M.D., Godcharles M.F., et al. 1992. Age, growth, and reproduction of jewfish Epinephelus itajara in the eastern Gulf of Mexico. Fish. Bull. 90: 243-249.

Castro A.L.F., Stewart B.S., Wilson S.G., et al. 2007. Population genetic structure of Earth's largest fish, the whale shark (Rhincodon typus). Mol. Ecol. 16: 5183-5192. http://dx.doi.org/10.1111/j.1365-294X.2007.03597.x

Chen S., Liu T., Li Z., et al. 2008. Genetic population structuring and demographic history of red spotted grouper (Epinephelus akaara) in South and East China Sea. Afr. J. Biotechnol. 7: 3554-3562.

Cohen M.C.L., Souza-Filho P.W., Lara, R.L., et al. 2005. A model of Holocene mangrove development and relative sea-level changes on the Bragança Peninsula (northern Brazil). Wetl. Ecol. Manag. 13: 433-443. http://dx.doi.org/10.1007/s11273-004-0413-2

Coleman F.C., Koenig C.C. 2010. The Effects of Fishing, Climate Change, and Other Anthropogenic Disturbances on Red Grouper and Other Reef Fishes in the Gulf of Mexico. Integr. Comp. Biol. 50 (2): 201-212. http://dx.doi.org/10.1093/icb/icq072

Coleman F.C., Scanlon K.M., Koenig C.C. 2011. Groupers on the Edge: Shelf Edge Spawning Habitat in and Around Marine Reserves of the Northeastern Gulf of Mexico. Prof. Geogr. 63(4): $1-19$ http://dx.doi.org/10.1080/00330124.2011.585076

Craig M.T., Hastings P.A. 2007. A molecular phylogeny of the groupers of the subfamily Epinephelinae with a revised classification of the tribe Epinephelini. Ichthyol. Res. 54: 1-17. http://dx.doi.org/10.1007/s10228-006-0367-x

Craig M.T., Hastings P.A., Pondella D.J., et al. 2006. Phylogeography of the flag cabrilla Epinephelus labriformis (Serranidae): implications for the biogeography of the Tropical Eastern Pacific and the early stages of speciation in a marine shore fish. J. Biogeogr. 33: 969-979. http://dx.doi.org/10.1111/j.1365-2699.2006.01467.x

Craig M.T., Graham R.T., Torres R.A., et al. 2009. How many species of goliath grouper are there Cryptic genetic divergence in a threatened marine fish and the resurrection of a geopolitical species. Endang. Species Res. 7: 167-174. http://dx.doi.org/10.3354/esr00117

Craig M.T., Sadovy de Mitcheson Y.J., Heemstra P.C. 2012. Groupers of the World: A Field and Market Guide, CRC Press. 424 pp.

Cunha I.M.C., Souza, A.S., Dias Jr. E.A., et al. 2014. Genetic Multipartitions Based on D-Loop Sequences and Chromosomal Patterns in Brown Chromis, Chromis multilineata (Pomacentridae), in the Western Atlantic. Hindawi BioMed Research International. Article ID 254698, $11 \mathrm{pp}$. http://dx.doi.org/10.1155/2014/254698

Drew J.A, Barber P.H. 2012. Comparative Phylogeography in Fijian Coral Reef Fishes: A Multi-Taxa Approach towards Marine Reserve Design. PLoS ONE 7(10): e47710. http://dx.doi.org/10.1371/journal.pone.0047710

Drummond A.J., Ashton B., Cheung M., et al. 2009. Geneious v4. 7, Available from http://www.geneious.com

Dupanloup I., Schneider S., Excoffier L. 2002. A simulated annealing approach to define the genetic structure of populations. Mol. Ecol. 11(12): 2571-2581. http://dx.doi.org/10.1046/j.1365-294X.2002.01650.x

Edgar R.C. 2004. MUSCLE: multiple sequence alignment with high accuracy and high throughput. Nucleic Acids Res. 32(5): 1792-1797. 
http://dx.doi.org/10.1093/nar/gkh340

Eklund A.M., Schull J. 2001. A stepwise approach to investigate the movement patterns and habitat utilization of goliath grouper, Epinephelus itajara, using conventional tagging, acoustic telemetry and satellite tracking. In: Sibert J.R. and Nielsen J.L. (eds) Electronic tagging and tracking in marine fisheries. Springer-Verlag, New York. pp. 189-216. http://dx.doi.org/10.1007/978-94-017-1402-0 g

Excoffier L., Laval L.G., Schneider S. 2005. Arlequin ver. 3.5: an integrated software package for population genetics data analysis. Evol. Bioinform. Online 1: 47-50.

Frias-Torres S. 2006. Habitat Use of Juvenile Goliath Grouper Epinephelus itajara in the Florida Keys, USA. Endang. Species Res. 1: 1-6. http://dx.doi.org/10.3354/esr002001

Giglio V.J., Adelir-Alves J., Gerhardinger L.C., et al. 2014. Habitat use and abundance of goliath grouper Epinephelus itajara in Brazil: a participative survey. Neotrop. Ichthyol. 12(4): 803-810. http://dx.doi.org/10.1590/1982-0224-20130166

Grant W.S., Bowen B.W. 1998. Shallow population histories in deep evolutionary lineages of marine fishes: Insights from sardines and anchovies and lessons for conservation. J. Hered. 89: $415-426$. http://dx.doi.org/10.1093/jhered/89.5.415

Hébert C., Danzman R.G., Jones M.W., et al. 2000. Hydrography and population genetic structure in brook charr (Salvelinus fontinalis, Mitchill) from eastern Canada. Mol. Ecol. 9: 971-982. http://dx.doi.org/10.1046/j.1365-294x.2000.00965.x

Hobbs J-P.A., Herwerden L.V., Jerry D.R., et al. 2013. High Genetic Diversity in Geographically Remote Populations of Endemic and Widespread Coral Reef Angelfishes (genus: Centropyge). Diversity 5: 39-50. http://dx.doi.org/10.3390/d5010039

Ingvarsson P.K. 2004. Population subdivision and the HudsonKreitman-Aguade test: testing for deviations from the neutral model in organelle genomes. Genet. Res. 83: 31-39. http://dx.doi.org/10.1017/S0016672303006529

IUCN. 2015. The IUCN (International Union for Conservation of Nature) Red List of Threatened Species. Version 2015.2. Downloaded on 27 July 2015. www.iucnredlist.org

Ji Y-Q., Wu D-D., Wu G-S., et al. 2011. Multi-Locus Analysis Reveals A Different Pattern of Genetic Diversity for Mitochondrial and Nuclear DNA between Wild and Domestic Pigs in East Asia. PLoS ONE 6(10): e26416. http://dx.doi.org/10.1371/journal.pone.0026416

Koenig C.C., Coleman F.C., Eklund A.M., et al. 2007. Mangroves as Essential Nursery Habitat for Goliath grouper (Epinephelus itajara). Bull. Mar. Sci. 80(3): 567-586.

Kumar S., Subramanian S. 2002. Mutation rates in mammalian genomes. Proc. Natl. Acad. Sci. USA 99: 803-808. http://dx.doi.org/10.1073/pnas.022629899

Leipe T., Knoppers B., Marone E., et al. 1999. Suspended matter transport in coral reef waters of the Abrolhos Bank, Brazil. GeoMarine Letters 19(3): 186-195. http://dx.doi.org/10.1007/s003670050108

Librado P., Rosas J. 2009. DnaSP v.5: A software for comprehensive analysis of DNA polymorphism data. Bioinformatics 25: 1451-1452. http://dx.doi.org/10.1093/bioinformatics/btp187

Mann D.A., Locascio J.V., Coleman F.C., et al. 2008. Goliath grouper Epinephelus itajara sound production and movement patterns on aggregation sites. Endang. Species Res. 7: 229-236. http://dx.doi.org/10.3354/esr00109

McClenachan L. 2009. Historical declines of goliath grouper populations in South Florida, USA. Endang. Species Res. 7: 175-181. http://dx.doi.org/10.3354/esr00167

Mora C., Sale P.F. 2002. Are populations of coral reef fishes open or closed? Trends Ecol. Evol. 17: 422-428. http://dx.doi.org/10.1016/S0169-5347(02)02584-3

Moura A., Shukla J. 1981. On the dynamics of droughts in northeast Brazil: Observations, theory and numerical experiments with a general circulation model. J. Atmos. Sci. 38: 2653-2675. http://dx.doi.org/10.1175/1520-0469(1981)038<2653:OTDOD $\mathrm{I}>2.0 . \mathrm{CO} ; 2$

Nonaka R.H., Matsuura Y., Suzuki K. 2000. Seasonal variation in larval fi sh assemblages in relation to oceanographic conditions in the Abrolhos Bank region off eastern Brazil. Fish. Bull. 98: 767-784.

Ostellari L., Bargelloni L., Penzo E., et al. 1996. Optimization of single-strand conformation polymorphism and sequence analy- sis of the mitochondrial control region in Pagellus bogaraveo (Sparidae, Teleostei): rationalized tools in fish population biology. Anim. Genet. 27: 423-427 http://dx.doi.org/10.1111/j.1365-2052.1996.tb00510.x

Palumbi S.R. 2003. Population Genetics, Demographic Connectivity, and the Design of Marine Reserves. Ecol. Appl. 13(1, Suppl.): 146-158.

http://dx.doi.org/10.1890/1051-0761(2003)013[0146:PGDCA T]2.0.CO;2

Palumbi S.R., Baker C.S. 1994. Contrasting Population Structure from Nuclear Intron Sequences and mtDNA of Humpback Whales. Mol. Biol. Evol. 11(3): 246-435.

Pesole G., Gissi C., De Chirico A., et al. 1999. Nucleotide substitution rate of mammalian mitochondrial genomes. J. Mol. Evol. 48: 427-434. http://dx.doi.org/10.1007/PL00006487

Pina-Amargós F., González-Sansón G. 2009. Movement patterns of goliath grouper Epinephelus itajara around southeast Cuba: implications for conservation. Endang. Species Res. 7: 243-247. http://dx.doi.org/10.3354/esr00192

Portnoy D.S., Hollenbeck C.M., Renshaw M.A., et al. 2013. Does mating behaviour affect connectivity in marine fishes? Comparative population genetics of two protogynous groupers (Family Serranidae). Mol. Ecol. 22: 301-313. http://dx.doi.org/10.1111/mec.12128

Rivera M.A., Kelley C.D., Roderic G.K. 2004. Subtle population genetic structure in the Hawaiian grouper, Epinephelus quernus (Serranidae) as revealed by mitochondrial DNA analyses. Biol. J. Linnean Soc. 81: 449-468. http://dx.doi.org/10.1111/j.1095-8312.2003.00304.x

Sadovy Y., Eklund A.M. 1999. Synopsis of biological information on the Nassau grouper, Epinephelus striatus, (Bloch 1792), and the jewfish, E. itajara (Lichtenstein 1822). NOAA Technical Report, NMFS 146, and FAO Fisheries Synopsis 157. 65 pp.

Sanger F., Air G.M., Barrell B.G., et al. 1977. Nucleotide sequence of bacteriophage $\varphi$ X174 DNA. Nature 265: 687-695. http://dx.doi.org/10.1038/265687a0

Schaeffer-Novelli Y., Cintron-Molero G., Adaime R.R. 1990. Variability of mangrove ecosystems along the brazilian coast. Estuaries 13(2): 201-218. http://dx.doi.org/10.2307/1351590

Seyoum S., Tringali M.D., Barthel B.L., et al. 2013. Isolation and characterization of 29 polymorphic microsatellite markers for the endangered Atlantic goliath grouper (Epinephelus itajara), and the Pacific goliath grouper (E. quinquefasciatus). Conservation Genet. Resour. 5: 729-732. http://dx.doi.org/10.1007/s12686-013-9892-x

Silva-Oliveira G.C., Rêgo P.S., Schneider H., et al. 2008. Genetic characterisation of populations of the critically endangered Goliath grouper (Epinephelus itajara, Serranidae) from the Northern Brazilian coast through analyses of mtDNA. Genet. Mol. Biol. 31(4): 988-994. http://dx.doi.org/10.1590/S1415-47572008005000016

Silva-Oliveira G.C., Silva A.B.C., Oliveira Y., et al. 2012. New nuclear primers for molecular studies of Epinephelidae fishes. Conservation Genet. Resour. 5: 165-168. http://dx.doi.org/10.1007/s12686-012-9759-6

Silva-Oliveira G.C., Silva A.B.C., Blanchard F., et al. 2014. Primers for the amplification of the MHC II $\beta$ chain exon 2 in the Atlantic goliath grouper (Epinephelus itajara). Conservation Genet. Resour. 6: 523-525. http://dx.doi.org/10.1007/s12686-014-0167-y

Soutelino R.G., Gangopadhyay A., Silveira I.C.A. 2013. The roles of vertical shear and topography on the eddy formation near the site of origin of the Brazil Current. Cont. Shelf Res. 70: 46-60. http://dx.doi.org/10.1016/j.csr.2013.10.001

Souza A.S., Dias Júnior E.A., Galetti P.M., et al. 2015. Wide-range genetic connectivity of Coney, Cephalopholis fulva (Epinephelidae), through oceanic islands and continental Brazilian coast. An. Acad. Bras. Cienc. 87(1): 121-136. http://dx.doi.org/10.1590/0001-3765201520130411

Suguio K., Bittencourt A.C.S.P., Dominguez J.M.L., et al. 1985. Flutuações do nível relativo do mar durante o quaternário superior ao longo do litoral brasileiro e suas implicacões na sedimentação costeira. Rev. Bras. Geociênc. 15: 273-286.

Tamura R., Peterson D., Peterson N., et al. 2011. MEGA 5: Molecular Evolutionary Genetics Analysis using Maximum Likehood, Evolutionary Distance and Maximum Parsimony Methods. Mol. Biol. Evol. 28: 2732-2739. http://dx.doi.org/10.1093/molbev/msr121 
Tang Q., Liu H., Mayden R., et al. 2006. Comparison of evolutionary rates in the mitochondrial DNA cytochrome b gene and control region and their implications for phylogeny of the Cobitoidea (Teleostei: Cypriniformes). Mol. Phylogenet. Evol. 39: 347-357.

http://dx.doi.org/10.1016/j.ympev.2005.08.007

Teixeira C.E.P., Lessa G.C., Cirano M., et al. 2013. The inner shelf circulation on the Abrolhos Bank, $18^{\circ} \mathrm{S}$, Brazil. Cont. Shelf Res. 70: 13-26. http://dx.doi.org/10.1016/j.csr.2013.09.003

Toews D.P.L., Brelsford A. 2012. The biogeography of mitochondrial and nuclear discordance in animals. Mol. Ecol. 21: 3907-3930 http://dx.doi.org/10.1111/j.1365-294X.2012.05664.X

Torres R.A., Feitosa R.B., Carvalho D.C., et al. 2013. DNA barcoding approaches for fishing authentication of exploited grouper species including the endangered and legally protected goliath grouper Epinephelus itajara. Sci. Mar. 77(3): 409-418. http://dx.doi.org/10.3989/scimar.03805.29A

Vasconcellos A.V., Vianna P., Paiva P.C., et al. 2008. Genetic and morphometric differences between yellowtail snapper (Ocyurus chrysurus, Lutjanidae) populations of the tropical West Atlantic. Genet. Mol. Biol. 31(1): 308-316.
http://dx.doi.org/10.1590/S1415-47572008000200026

Wasko A.P., Martins C., Oliveira C., et al. 2003. Non-destructive genetic sampling in fish. An improved method for DNA extraction from fish fins and scales. Hereditas 138: 161-165. http://dx.doi.org/10.1034/j.1601-5223.2003.01503.x

Wright S. 1951. The genetical structure of populations. Ann. Eugen. 15: 323-354 http://dx.doi.org/10.1111/j.1469-1809.1949.tb02451.x

Zabel M., Wagner T., deMenocal P. 2003. Terrigenous signals in sediments from Terrigenous Signals in Sediments of the LowLatitude Atlantic - Indications to Environmental Variations during the Late Quaternary, Part II: Lithogenic Matter. In: Wefer G., Mulitza S., Ratmeyer V. (eds), The South Atlantic in the Late Quaternary: Reconstruction of Mass Budget and Current Systems, Springer-Verlag, Berlin, Heidelberg, New York. pp. 323-345. http://dx.doi.org/10.1007/978-3-642-18917-3_16

Zhang J., Cai Z., Huang L. 2006. Population genetic structure of crimson snapper Lutjanus erythropterus in East Asia, revealed by analysis of the mitochondrial control region. ICES J. Mar. Sci. 63: 693-704.

http://dx.doi.org/10.1016/j.icesjms.2006.01.004 